\title{
EPIDEMIOLOGY OF HIP PAIN IN BRAZILIAN BODYBUILDERS
}

\section{EPIDEMIOLOGIA DA DOR NO QUADRIL EM FISICULTURISTAS BRASILEIROS}

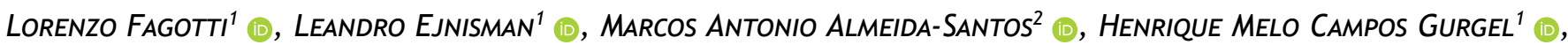 \\ HELDER DE SOUZa MIYAHARA ${ }^{1}$ (1), ANDRE PEDRINELLI ${ }^{1}$ (1)
}

1. Universidade de São Paulo, Medical School, Orthopedics and Traumatology Institute, São Paulo, SP, Brazil.

2. Universidade Tiradentes, Postgraduate Program in Health and Environment, Aracajú, SE, Brazil.

\section{ABSTRACT}

Objective: To determine the frequency of hip pain in competitive bodybuilders over three different bodybuilding competitions. Methods: This study evaluated bodybuilders recruited from three competitions during the year of 2016. All participants provided their informed consent and the study received IRB approval. Training routine, health condition, level of success on competitions, history of hip pain and physical examination of the hip were evaluated. Results: 113 bodybuilders were evaluated, mean age was $30.5 \pm 8.65$ years and mean BMI was $25.2 \pm 3.65 \mathrm{~kg} /$ $\mathrm{m}^{2}$. Mean values for hip flexion, adduction, abduction, internal rotation, external rotation and distance between the knee and the table (FABER distance) were $116 \pm 13,23 \pm 8,71 \pm 12$, $40 \pm 10,36 \pm 9$ and $19 \pm 4$, respectively. Eight (7\%) participants presented hip pain within the week prior to examination and only $2(1,7 \%)$ presented with anterior impingement sign. None of the athletes who reported hip pain interrupted their physical training or performance. Conclusion: Symptomatic athletes continued their training program under the presence of hip pain. The frequency of hip pain among bodybuilders is high and may be underestimated in this study. Level of Evidence IV, Case series.

Keywords: Hip Joint. Arthralgia. Resistance Training. Femoracetabular Impingement.

\section{RESUMO}

Objetivo: Determinar a frequência de dor no quadril em atletas fisiculturistas durante três competições de fisiculturismo. Métodos: Este estudo avaliou fisiculturistas recrutados em três competições de fisiculturismo durante o ano de 2016. Termo de consentimento foi obtido de todos os participantes, e também foi obtido a aprovação do CEP. Rotina de treinos, condição de saúde, nível de sucesso nas competições, antecedente de dor no quadril ao exame físico foram avaliados. Resultados: Um total de 113 fisiculturistas foram avaliados, com idade e IMC médio de $30.5 \pm 8.65$ anos e $25.2 \pm 3.65 \mathrm{~kg} / \mathrm{m} 2$, respectivamente. O valor médio de flexão, adução, abdução, rotação interna, rotação externa do quadril, e distância entre o joelho e a mesa de exame (distância FABERE) foi de $116 \pm 13,23 \pm 8,71 \pm 12$, $40 \pm 10,36 \pm 9$ e $19 \pm 4$, respectivamente. Oito (7\%) participantes apresentavam dor no quadril dentro da última semana antes de serem examinados, e apenas dois (1.7\%) apresentavam sinal do impacto anterior do quadril à manobra de flexão adução e rotação interna. A dor no quadril não afetou o treinamento físico e a performance dos atletas que reportaram dor no quadril. Conclusão: Atletas sintomáticos continuaram o programa de treinamento mesmo na presença de dor no quadril. A frequência de dor no quadril de atletas fisiculturistas é alta e pode ter sido subestimada neste estudo. Nível de Evidência IV, Série de casos.

Descritores: Articulação do Quadril. Artralgia. Treinamento de Resistência. Impacto Femoroacetabular.

Citation: Fagotti L, Ejnisman L, Almeida-Santos MA, Gurgel HMC, Miyahara HS, Pedrinelli A. Epidemiology of hip pain in Brazilian bodybuilders. Acta Ortop Bras. [online]. 2021;29(3):124-126. Available from URL: http://www.scielo.br/aob.

\section{INTRODUCTION}

Hip pain is frequently diagnosed in running and football athletes, where athletes are prone to change-of-direction movements and different movement strategies., ${ }^{1,2}$ However, studies on hip injuries in other sports activities remain scarce. In strength sports, physical and mental stress associated to weight gain during "off-season" may contribute to an increased risk of injury, particularly on the hip, knees and sacroiliac joints. ${ }^{3}$ According to a recent systematic review, up to $31 \%$ of all injuries among weightlifters and powerlifters involve the groin or hip joint. ${ }^{4}$ Peripheral nerve injuries, especially involving the femoral nerve, are also reported in bodybuilders. ${ }^{5}$ Hip injuries are known to be a common cause of pain in high level athletes such as bodybuilders and weightlifters. Bodybuilding culture has grown together with the opening of numerous fitness centers, with the popularity of competitions growing over the last decades. Several championships with different categories take place across Brazil and athletes frequently have to change their exercise regimen. Competitive bodybuilding athletes usually join

All authors declare no potential conflict of interest related to this article.

The study was conducted at Universidade de São Paulo, Faculty of Medicine, Hospital das Clínicas, Institute of Orthopedics and Traumatology. Correspondence: Lorenzo Fagotti. Rua Dr. Ovídio Pires de Campos, 333, São Paulo, SP, Brazil, 05403010. lorenzo_fagotti@hotmail.com 
qualifying series, and the nutritional and exercise routine can vary significantly between "on-season" and "off-season" cycles.

These athletes frequently lift a large amount of weight from squatting position. The squat using loaded barbells requires appropriate technique and is performed by flexing the hips and knees, keeping the lower limbs parallel until the thighs are parallel to the floor. If not done appropriately according to the specific body type, this intense routine of workouts can severely hurt the athletes' hip due to labral tearing. The frequency of disorders on the hip of bodybuilders is about $5.6 \%$ of all injuries, as reported by Siewe et al. ${ }^{6}$ Femoroacetabular impingement (FAl) is a severe but treatable injury and is caused by a bony anatomical deformity that causes the hip joint to impinge, which can lead to subchondral or intra-articular damage and pain. This condition may affect some exercises performed by bodybuilders, in particular, squatting. ${ }^{7}$ However, a recent study found no differences in squat depth when comparing patients with and without symptomatic FAl. ${ }^{8}$

So far there are no reports about hip pain and $\mathrm{FAI}$ in Brazilian bodybuilders, and the risks of hip injuries are unknown. Athletes with symptomatic FAI do not present differences in hip joint range of movement if functional impairments in hip muscle strength and balance of the lower limbs are present. ${ }^{9}$ Our goals in this study were to identify the incidence of hip pain and then examine the risk factors for groin/hip injuries among bodybuilders.

\section{MATERIALS AND METHODS}

This is cohort study with epidemiological collected data from questionnaires and physical examination of the hip of Brazilian weightlifters. Participants were recruited from two regional and one national bodybuilding competitions. This study obtained approval from the local IRB (n.14969/CAI 56997116.0.0000.0065). Informed consent was obtained from all the participants.

Athletes were included based on their volunteer participation. Individuals from different weight categories were included; they were interviewed and examined one day before the competition. The interviewer was an orthopedic surgeon who also performed the physical examination of the hip. After answering the questionnaire, the participants were physically evaluated at an appropriate and private room.

The questionnaire evaluated frequency, duration, weight lifted on squatting, years of training, the success on competitions (regional, national, international), and past history of hip pain or injury. The physical evaluation consisted of measuring weight, height and range of motion with a goniometer for hip flexion, adduction, abduction, supine and prone internal rotation. In addition, two specific tests for FAI were included: the FADIR test (flexion, adduction and internal rotation of the hip) (Figure 1) and the distance between the lateral genicular line of the knee and the exam table in supine. This distance is called the Flexion Abduction External Rotation (FABER) distance and is frequently used as a clinical parameter for assessing femoracetabular impingement. ${ }^{1}$

Patients who presented pain in the physical evaluation received orientation about their symptoms and possible etiologies of the pain. The medical team also provided a list of referral hospitals and diagnostic procedures.

\section{Statistical Analysis}

Continuous variables were expressed as mean and standard deviation, or median and interquartile range when the distribution curve was not normal. The assumption of a normal distribution was assessed by the histogram and the quantile-quantile plots, followed by the Shapiro-Wilk test. Categorical variables were expressed in absolute number and percentage. Comparisons between continuous variables involving a given group were performed by the Student's t test for normal distribution patterns, or by the nonparametric Mann-Whitney's test, otherwise. Comparisons between categorical variables were performed using Fisher's exact test.

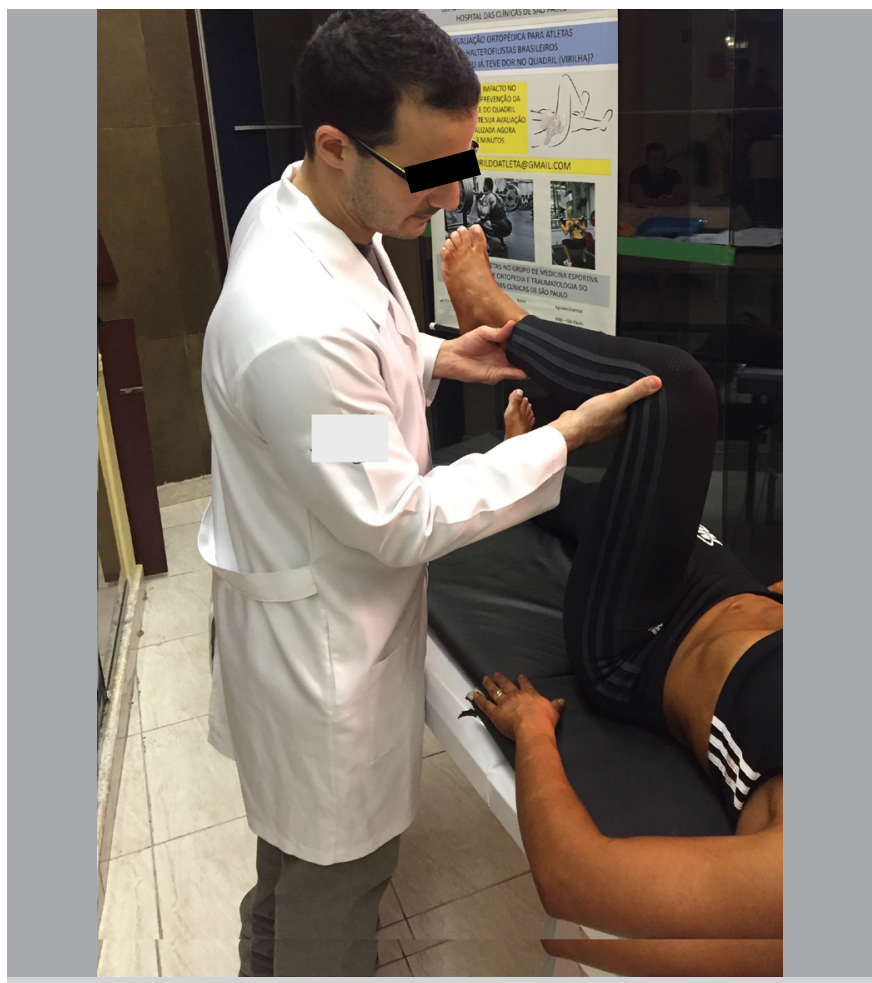

Figure 1. Anterior hip impingement test, athlete in supine position.

\section{RESULTS}

Between April 2016 and July 2016, 113 bodybuilders completed the questionnaire and underwent the physical examination of the hip. In total, 113 bodybuilders, 46 (40.7\%) female and $67(59.3 \%)$ male athletes, were evaluated. The mean age was $30.5 \pm 8.65$ years and mean BMI was $25.2 \pm 3.65 \mathrm{~kg} / \mathrm{m}^{2}$. Mean hip flexion, adduction, abduction, internal rotation, external rotation and distance between the knee and the table (FABER distance) were $116 \pm 13,23 \pm 8,71 \pm 12,40 \pm 10,36 \pm 9$ and $19 \pm 4$, respectively. Eight (7\%) participants presented with hip pain within the week prior to examination and $2(1.7 \%)$ presented with anterior impingement sign during physical examination. Hip pain did not affect physical training or athlete's performance in the athletes who reported it. The baseline data according to the presence of hip pain within the week prior to the physical examination is displayed in Tables 1 and 2 .

Table 1. Demographics and training regimen according to the presence of hip pain.

\begin{tabular}{c|c|c|c}
\hline & $\begin{array}{c}\text { Hip pain } \\
(\mathbf{n}=8)\end{array}$ & $\begin{array}{c}\text { No hip pain } \\
(\mathbf{n}=105)\end{array}$ & P value \\
\hline Age (years) & $30.8 \pm 8.7$ & $30.7 \pm 8.7$ & 0.49 \\
\hline Gender (M:F) & $3: 5$ & $64: 41$ & 0.19 \\
\hline BMl $\left(\mathrm{Kg} / \mathrm{m}^{2}\right)$ & $25.2 \pm 5.3$ & $25.1 \pm 3.4$ & 0.33 \\
\hline Squat weight $(\mathrm{Kg})$ & $115.6 \pm 74.2$ & $113.5 \pm 50.8$ & 0.34 \\
\hline Frequency (weeks) & $5.6 \pm 0.5$ & $5.6 \pm 1.2$ & 0.12 \\
\hline Time of training (minutes) & $70.5 \pm 34.9$ & $69.7 \pm 24.9$ & 0.47 \\
\hline Time training (years) & $6.3 \pm 7.2$ & $6 \pm 5.8$ & 0.68 \\
\hline
\end{tabular}

BMI: body mass index. 
Table 2. Range of motion (right hip) according to the presence of hip pain.

\begin{tabular}{c|c|c|c}
\hline & Hip pain $(\mathbf{n}=8)$ & No hip pain $(\mathbf{n}=105)$ & P value \\
\hline Flexion $\left(^{\circ}\right)$ & $116.2 \pm 11.4$ & $115.2 \pm 9.9$ & 0.01 \\
\hline Adduction $\left(^{\circ}\right)$ & $23.6 \pm 7.8$ & $23.3 \pm 6.3$ & 0.37 \\
\hline Abduction $\left(^{\circ}\right)$ & $70.8 \pm 8.8$ & $69.9 \pm 10.2$ & 0.03 \\
\hline Internal Rotation 0 $\left(^{\circ}\right)$ & $37.6 \pm 9.4$ & $37.1 \pm 9.2$ & 0.30 \\
\hline External Rotation 0 $\left(^{\circ}\right)$ & $35.7 \pm 6.9$ & $35 \pm 9.1$ & 0.70 \\
\hline Internal Rotation $90\left(^{\circ}\right)$ & $39.2 \pm 11$ & $38.4 \pm 11.2$ & 0.03 \\
\hline External Rotation $90\left(^{\circ}\right)$ & $35.8 \pm 11.3$ & $35.7 \pm 9$ & 0.37 \\
\hline FABER Distance $(\mathrm{cm})$ & $18.5 \pm 4.8$ & $18.7 \pm 4.6$ & 0.63 \\
\hline
\end{tabular}

FABER: flexion abduction external rotation.

\section{DISCUSSION}

The frequency of hip pain in competitive bodybuilders was $7 \%$ in the present study, which is considerably higher than the $0.6 \%$ incidence found in the general population. ${ }^{10}$ The mean age of our study population was 30.5 years, being considered a young population of active bodybuilders. Among the patients with hip pain, 2 (25\%) were clinically diagnosed with FAI, similar to rates reported from the general population. ${ }^{10}$ Siewe et al. ${ }^{6}$ found 0.12 injuries per bodybuilder as the incidence in a similar population, and the rate of hip disorders was 5.6\%. Our study also found that the presence of hip pain among bodybuilders did not affect the athlete's performance and interruptions of training or competition were low. We believe the rate of hip pain is underestimated in this particular population due to possible fear of the athlete in reporting a physical disability just before the competition. Athletes face stress in the days leading up to a competition, mainly because of the need to keep their weight within the limits of their category.

Hip pain was reported by 8 out of 113 athletes, and only $2(1.7 \%)$ presented positive results in the anterior hip impingement test. The anterior hip impingement sign indicates the presence of an intra-articular injury, which may be present in 5\% of the total hip athletic injuries of the hip. ${ }^{2}$ Two athletes showed positive signs during physical examination. One female participant had bilateral positive hip impingement test and signs of joint laxity. Patients with soft tissue laxity are sometimes difficult to diagnose. ${ }^{11}$ Moreover, this patient was an amateur running athlete before starting her bodybuilder career. Since this study is a cohort epidemiological one, further investigation with previous imaging of the hip was not the focus of our study. The other patient, also a female, had unilateral symptoms and did not mention practicing other sports activities prior to bodybuilding.
Sagittal pelvic mobility allows adequate trunk flexion during squatting. ${ }^{12}$ All athletes reported squatting as part of their training routine. Squatting is a risk factor for femoracetabular impingement ${ }^{13,14}$ and athletes reported to lift up to $250 \mathrm{~kg}$ during squatting. Although the difference between symptomatic and asymptomatic groups was not statistically significant, studies on the relationship between squatting and femoracetabular impingement should be encouraged. Low back pain was described as the most prevalent injury in a population of competitive weightlifters. ${ }^{15}$ All three tournaments had categories for athletes with age greater than the average; however, none of the athletes over 35 years old reported hip pain, but many reported low back pain. Regarding the physical examination, most of the athletes in this study have not distinguished between a groin and a lateral pain. The lack of knowledge about femoracetabular impingement can contribute not only to the continuation of training despite the presence of hip pain, but also to a more difficult recognition of the initial symptoms of hip disorders. Regarding the range of motion, statistically significant differences were found for flexion, abduction and external rotation $(p<0.05)$. However, these differences were minimal and probably do not present any clinical relevance. Moreover, these differences may be related to possible variation of the measurements with the goniometer. In addition, some patients were not completely comfortable during hip examination due to the stress faced on the day before the competition. FABER distances were similar between symptomatic and asymptomatic athletes in our study, which may be explaind by the heterogeneity of the studied population. Many athletes reported previous practice of other sports in addition to bodybuilding. Furthermore, many athletes were not completely sure about when they started their bodybuilding training, so recreational weightlifting could have been considered as part of their official preparation for the competition. Another limitation was the smaller group of symptomatic patients and imbalanced comparison groups.

\section{CONCLUSION}

Our study found an incidence of hip pain of $7 \%$ among competitive bodybuilders. Only 2 (1.7\%) patients were clinically symptomatic for femoracetabular impingement. Although the frequency of hip pain among bodybuilders is considered high, it did not alter athlete's performance.

\section{ACKNOWLEDGEMENTS}

We acknowledge Ayumi Saito Tomishige and Diego Rubio Jamarillo for their great support in data collection.

AUTHORS' CONTRIBUTIONS: Each author contributed individually and significantly to the development of this article. LF: writing and data analysis; LE: review of the article and intellectual conception of the article; MAAS: data analysis; HMCG: review of the article; HSM: review of the article; AP: review of the article and intellectual conception of the article.

\section{REFERENCES}

1. Philippon MJ, Maxwell RB, Johnston TL, Schenker M, Briggs KK. Clinical presentation of femoroacetabular impingement. Knee Surg Sports Traumatol Arthrosc. 2007;15(8):1041-7

2. Feeley BT, Powell JW, Muller MS, Barnes RP, Warren RF, Kelly BT. Hip injuries and labral tears in the national football league. Am J Sports Med. 2008;36(11):2187-95.

3. Lavallee ME, Balam T. An overview of strength training injuries: acute and chronic. Curr Sports Med Rep. 2010;9(5):307-13.

4. Aasa U, Svartholm I, Andersson F, Berglund L. Injuries among weightlifters and powerlifters: a systematic review. Br J Sports Med. 2017;51(4):211-9

5. Radi B, Radi P, Durakovi D. Peripheral nerve injury in sports. Acta Clin Croat. 2018;57(3):561-9.

6. Siewe J, Marx G, Knöll P, Eysel P, Zarghooni K, Graf M, et al. Injuries and overuse syndromes in competitive and elite bodybuilding. Int J Sports Med. 2014;35(11):943-8

7. Cheatham SW, Stull KR, Fantigrassi M, Montel I. Hip Musculoskeletal Conditions and Associated Factors That Influence Squat Performance: A Systematic Review. J Sport Rehabil. 2018;27(3):263-73.
8. Diamond LE, Bennell KL, Wrigley TV, Hinman RS, O'donnell J, Hodges PW. Squatting Biomechanics in Individuals with Symptomatic Femoroacetabular Impingement. Med Sci Sports Exerc. 2017;49(8):1520-9.

9. Freke MD, Kemp J, Svege I, Risberg MA, Semciw A, Crossley KM. Physical impairments in symptomatic femoroacetabular impingement: a systematic review of the evidence. Br J Sports Med. 2016;50(19):1180.

10. Röling MA, Mathijssen NMC, Bloem RM. Incidence of symptomatic femoroacetabular impingement in the general population: a prospective registration study. J Hip Preserv Surg. 2016;3(3):203-7.

11. Braly BA, Beall DP, Martin HD. Clinical examination of the athletic hip. Clin Sports Med. 2006;25(2):199-210.

12. Beck M, Leunig M, Parvizi J, Boutier V, Wyss D, Ganz R. Anterior femoroacetabular impingement: Part II. midterm results of surgical treatment. Clin Orthop Relat Res. 2004;(418):67-73.

13. Lamontagne M, Kennedy MJ, Beaulé PE. The effect of cam FAI on hip and pelvic motion during maximum squat. Clin Orthop Relat Res. 2009;467(3):645-50.

14. Polesello GC, Cinagawa EHT, Cruz PDSS, Queiroz MC, Borges CJ, Ricioli W $\mathrm{Jr}$, et al. Surgical treatment for femoroacetabular impingement in a group that performs squats. Rev Bras Ortop. 2015;47(4):488-92.

15. Calhoon G, Fry AC. Injury Rates and Profiles of Elite Competitive Weightlifters. J Athl Train. 1999;34(3):232-8. 